\title{
Pengaruh Pengetahuan dan Sikap Terhadap Kesiapsiagaan Kepala Keluarga dalam Menghadapi Bencana Banjir
}

\author{
${ }^{1}$ Santi Yatnikasari, ${ }^{2}$ Sigiet Haryo Pranoto, ${ }^{1}$ Fitriyati Agustina \\ ${ }^{1}$ Program Studi Teknik Sipil, Universitas Muhammadiyah Kalimantan Timur \\ 2 Program Studi Teknik Mesin, Universitas Muhammadiyah Kalimantan Timur \\ e-mail: sy998@umkt.ac.id
}

\begin{abstract}
Abstrak
Banjir merupakan bencana alam yang perlu mendapat perhatian, karena mengancam jiwa dan ekonomi masyarakat. Samarinda adalah ibukota Kalimantan Timur, merupakan salah satu kota yang masih selalu didera dengan permasalahan banjir. Tujuan penelitian ini adalah untuk mengetahui seberapa besar pengaruh pengetahuan dan sikap tentang resiko bencana banjir terhadap kesiapsiagaan kepala keluarga dalam menghadapi bencana banjir. Populasi dalam penelitian ini adalah warga di Kelurahan Sempaja Timur Kecamatan Samarinda Utara Kota Samarinda sejumlah 735 kepala keluarga dan ditetapkan sampel adalah 199 kepala keluarga. Penelitian ini menggunakan Metode campuran (Mixed Method) memadukan pendekatan kualitatif dan kuantitatif. Instrumen data diambil menggunakan kuesioner dan dianalisa dengan analisis statistik regresi linier, serta uji statistik uji $F$. Hasil penelitian menunjukkan terdapat pengaruh yang signifikan antara pengetahuan dan sikap terhadap tingkat kesiapsiagaan kepala keluarga dalam menghadapi bencana banjir di Kelurahan Sempaja Timur. Hal ini dibuktikan pada persamaan regresi linier berganda : $Y=10.282+0.243 X 1+0.034 X 2$, dan hasil uji $F$ dengan tingkat signifikansi $\alpha=0.05$ diperoleh nilai $F$ hitung sebesar 8.031 dan $P$ value sebesar $0.000<0.05$, maka variabel pengetahuan dan sikap mempunyai pengaruh yang signifikan secara simultan terhadap variabel kesiapsiagaan. Indeks gabungan dari empat parameter yaitu pengetahuan dan sikap, rencana tanggap darurat, mobilisasi sumber daya dan sistem peringatan banjir mencapai 73.26. Angka ini dalam klasifikasi indeks kesiapsiagaan termasuk kategori siap. Penelitian ini diharapkan dapat menambah wawasan kepala keluarga yang merupakan bagian dari masyarakat untuk meningkatkan kesadaran pentingnya pengetahuan dan kesiapsiagaan tentang bencana banjir.
\end{abstract}

Kata kunci: Pengetahuan; Sikap; Kesiapsiagaan Banjir.

\begin{abstract}
Floods are natural disasters that need attention because they threaten people's lives and economies. Samarinda is the capital city of East Kalimantan, one of the cities that is always plagued by flood problems. The purpose of this study was to determine how much influence the knowledge and attitudes about the risk of floods have on the preparedness of the head of the family in facing flood disasters. The population in this study was 735 households in the Sempaja Timur village, North Samarinda district, Samarinda city, and the sample was 199 households. This study uses a mixed-method that combines qualitative and quantitative approaches. The data instrument was taken using a questionnaire and analyzed with linear regression statistical analysis, and F-test statistical test. The results showed that there was a significant influence of knowledge and attitudes on the level of family head preparedness in facing floods in East Sempaja Village. This is proven in the multiple linear regression equation: $Y=10.282+0.243 X 1$ $+0.034 X 2$, and the results of the F-test with a significance level of $\alpha=0.05$ obtained a calculated $F$ value of 8.031 and a $P$ value of $0.000<0.05$, therefore knowledge and attitudes variable have simultaneous significant influences on the preparedness variable. The combined index of four parameters, namely knowledge and attitude, emergency response plans, resource mobilization and flood warning systems was 73.26. In the preparedness index classification, this number is in the ready category. This research is expected to give insight to the head of the family who is part of the community to increase awareness of the importance of knowledge and preparedness regarding flood disasters.
\end{abstract}

Keywords: Knowledge; Attitude; Flood Preparedness 


\section{Pendahuluan}

Bencana adalah rangkaian peristiwa yang mengancam dan mengganggu kehidupan masyarakat baik yang disebabkan oleh faktor alam atau non alam, maupun faktor manusia sehingga mengakibatkan timbulnya korban jiwa, kerusakan lingkungan, kerugian harta benda dan dampak psikologis (UU No. 24, 2007). Menurut Aryono (2011) banjir merupakan bencana alam yang perlu mendapat perhatian, karena mengancam jiwa dan ekonomi masyarakat dan merupakan bencana alam yang ketiga terbesar di dunia yang telah banyak menelan korban jiwa dan kerugian harta benda. Berdasarkan data Badan Nasional Penanggulangan Bencana (2019) bencana terbanyak yang terjadi di Indonesia adalah bencana hidrometereologi yang didominasi oleh tanah longsor, banjir, puting beliung, dan gempa bumi. Banjir dengan jumlah kejadian 1.275, mengakibatkan korban terbanyak dibanding kejadian lainnya.

Kota Samarinda adalah ibukota Kalimantan Timur yang masih selalu didera dengan permasalahan banjir. Fenomena kejadian banjir terjadi tidak hanya pada saat musim penghujan namun pada hujan dengan durasi 3 jam saja sebagian kawasan di Kota Samarinda tergenang. Sejarah mencatat banjir terbesar Samarinda terjadi pada tahun 1998 dan 2008 silam. Kembali terjadi lagi tahun 2019. Berdasarkan data Badan Penanggulangan Bencana Daerah Kota Samarinda (2019), warga korban banjir di Samarinda Kalimantan Timur terdeteksi sebanyak 30.580 jiwa, yakni di Kecamatan Samarinda Utara, Sungai Pinang dan Samarinda Ulu. Daerah yang paling parah adalah kelurahan Sempaja Timur kecamatan Samarinda Utara, dengan jumlah penduduk yang terkena bencana adalah 2.327 jiwa. Banjir merendam sejumlah kawasan di Samarinda, hal ini disebabkan karena tingginya intensitas hujan di Samarinda, dan pasangnya anak Sungai Karang Mumus. Sehingga berdampak rumah warga terendam banjir dengan ketinggian $25 \mathrm{~cm}$ sampai dengan $75 \mathrm{~cm}$. Menurut Bakornas (2007) banyaknya korban dan kerugian besar pada bencana tersebut menggambarkan kurangnya pemahaman tentang karakterisitik bahaya, sikap atau perilaku yang mengakibatkan penurunan sumber daya alam, kurangnya informasi peringatan dini yang mengakibatkan ketidaksiapan, dan ketidakberdayaan atau ketidakmampuan dalam menghadapi bencana.

Masyarakat harus berperan serta untuk bersiap sedia menghadapi ancaman banjir dengan persiapan dini, serta pengetahuan yang cukup untuk menghadapi bencana banjir. Pengetahuan yang dimiliki oleh seseorang atau masyarakat secara tidak langsung akan mempengaruhi sikap dan perilaku terutama dalam mengantisipasi setiap 
kejadian bencana yang terjadi. Kesiapsiagaan merupakan faktor penting yang menjadi fokus perhatian dewasa ini mengingat kesiapsiagaan adalah faktor penentu untuk pengurangan resiko bencana yang dapat dilakukan dan diupayakan sejak dini (LIPIUNESCO, 2006). Kesiapsiagaan dalam menghadapi bencana banjir akan membantu masyarakat dalam membentuk dan merencanakan tindakan apa saja yang perlu dilakukan ketika banjir. Kesuksesan dalam penanganan dan evakuasi/pengungsian ketika banjir sangat bergantung dari kesiapsiagaan masyarakat dan perseorangan itu sendiri. Adapun tujuan dari penelitian ini adalah untuk mengetahui seberapa besar pengaruh pengetahuan terhadap kesiapsiagaan masyarakat dalam menghadapi bencana banjir.

\section{Metode}

Lokasi penelitian terletak di Kelurahan Sempaja Timur Kecamatan Samarinda Utara Kota Samarinda. Secara adminstratif Kelurahan Sempaja Timur berada di Kecamatan Samarinda Utara Kota Samarinda, dapat dilihat pada gambar 1. Penelitian dilakukan dengan memadukan pendekatan kualitatif dan kuantitatif (Mix Method). Metode ini memberikan asumsi filosofis dalam menunjukkan arah atau memberi petunjuk cara pengumpulan data dan menganalisis data, serta perpaduan pendekatan kualitatif dan kuantitatif melalui beberapa fase proses penelitian (Sugiyono, 2013). Populasi adalah obyek yang dituju untuk diteliti oleh peneliti (Arikunto, 2010). Dalam penelitian ini yang menjadi obyek penelitian adalah masyarakat yang bertempat tinggal di Kelurahan Sempaja Timur Kecamatan Samarinda Utara Kota Samarinda. Berdasarkan data populasi masyarakat di Kelurahan Sempaja Timur Kecamatan Sempaja Kota Samarinda adalah 735 KK. Sampel adalah bagian dari jumlah dan karakteristik yang dimiliki oleh populasi tersebut (Sugiyono, 2013). Teknik pengambilan sampel dalam penelitian ini menggunakan bantuan tabel penentuan sampel (Isaac dan Michael dalam Sugiyono, 2013). Jumlah sampel yang diperoleh dari tabel penentuan sampel adalah 199. 


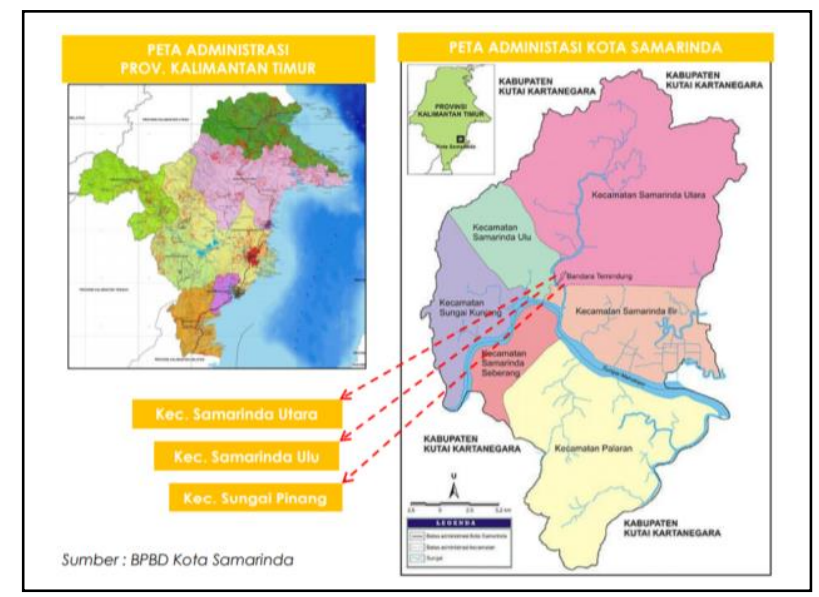

Gambar 1 Lokasi Penelitian

Analisis deskriptif pada penelitian ini menggunakan persentase. Data pada analisis diperoleh dari hasil tes dan skor angket yang telah diisi oleh responden. Klasifikasi persentase untuk kriteria pengetahuan menggunakan tabel kriteria tingkat variabel seperti pada tabel 1.

Tabel 1 Kriteria tingkat variabel

\begin{tabular}{ccc}
\hline No & Interval & Kriteria \\
\hline 1 & $<41 \%$ & Sangat Rendah \\
2 & $41 \%-60 \%$ & Rendah \\
3 & $61 \%-80 \%$ & Tinggi \\
4 & $81 \%-100 \%$ & Sangat Tinggi \\
\hline Sumber: Analisis Data Penelitian &
\end{tabular}

Sedangkan untuk kriteria sikap menggunakan tabel Kriteria Sikap pada tabel 2.

Tabel 2 Kriteria sikap

\begin{tabular}{cc}
\hline Interval & Kriteria Persentase \\
\hline $86 \%-100 \%$ & Sangat Baik \\
$71 \%-85 \%$ & Baik \\
$56 \%-70 \%$ & Cukup Baik \\
$41 \%-55 \%$ & Kurang Baik \\
$<41 \%$ & Tidak Baik \\
Sumber: Analisis Data Penelitian
\end{tabular}

Selanjutnya analisis indeks digunakan untuk mengukur tingkat kesiapsiagaan kepala keluarga menghadapi bencana banjir. Indeks tingkat kesiapsiagaan dapat dilihat pada tabel 3.

\begin{tabular}{cc} 
Tabel 3 Indeks tingkat kesiapsiagaan bencana \\
\hline Nilai Indeks & Kategori \\
\hline $80 \%-100 \%$ & Sangat Siap \\
$65 \%-79 \%$ & Siap \\
$55 \%-64 \%$ & Hampir Siap \\
$40 \%-54 \%$ & Kurang Siap \\
$<40 \%$ & Belum Siap \\
\hline
\end{tabular}

Sumber: LIPI-UNESCO, 2006 
Menurut LIPI-UNESCO (2006) untuk menentukan nilai indeks per parameter, maka digunakan rumus sebagai berikut:

$$
\text { indeks }=\frac{\text { Jumlah Skor Riil Parameter }}{\text { Skor Maksimum Parameter }} \times 100
$$

Sedangkan nilai indeks gabungan dari beberapa parameter dihitung dengan menggunakan rumus sebagai berikut:

Indeks Kepala Keluarga $(K K)=(0,45 *$ indeks $P)+(0,35 *$ indeks $R T D)+$

$(0,15 *$ indeks $M S D)+(0,05 *$ indeks $P B)$

Tabel 4 Bobot masing-masing parameter pada indeks kepala keluarga

\begin{tabular}{cccccc}
\hline \multicolumn{5}{c}{ Kepala Keluarga } \\
\hline Parameter & $\begin{array}{c}\text { Pengetahuan } \\
\text { dan Sikap }\end{array}$ & $\begin{array}{c}\text { Rencana } \\
\text { Tanggap Darurat }\end{array}$ & $\begin{array}{c}\text { Mobilisasi } \\
\text { Sumber Daya }\end{array}$ & $\begin{array}{c}\text { Peringatan } \\
\text { Bencana }\end{array}$ & Jumlah \\
\hline Bobot & 45 & 35 & 15 & 5 & 100 \\
\hline Sumber: LIPI-UNESCO, 2006 & & & &
\end{tabular}

Analisis statistik diawali dengan melakukan uji validitas dan reabilitas untuk mengukur kelayakan alat ukur, guna menentukan item indikator mana yang layak untuk diikutsertakan dalam perhitungan regresi. Kriteria yang digunakan untuk uji validitas mengacu kepada rumus:

$$
d f=n-2(\text { dengan sig } 5 \%)
$$

Dengan ketentuan apabila $r_{\text {hitung }}>r_{\text {tabel}}$, maka dikatakan item tersebut valid.

Sedangkan uji reabilitas, jika nilai Cronbach's Alpha $>0,60$, maka instrumen penelitan reliabel. Selanjutnya dapat dilakukan pengolahan data melalui analisis regresi linier dengan memasukan semua variabel penelitian yang telah valid dan reliabel.

Dari persamaan regresi, apabila pada variabel pengetahuan (X1) bernilai positif maka dikatakan bahwa variabel tersebut berpengaruh positif terhadap variabel kesiapsiagaan (Y). Begitupula varibel sikap (X2), apabila bernilai positif maka dapat dikatakan bahwa variabel tersebut berpengaruh positif terhadap variabel kesiapsiagaan (Y).

Uji $F$ pada penelitian ini merupakan uji yang dilakukan untuk mengetahui hubungan antara variabel independen dan variabel dependen, apakah pengetahuan (X1) dan sikap (X2) benar-benar berpengaruh secara simultan (bersama-sama) terhadap variabel dependen kesiapsiagaan $(Y)$. Dengan menentukan formulasi hipotesis:

- H0: $\beta 1=\beta 2=0$, artinya variabel pengetahuan $(X 1)$ dan sikap (X2) tidak mempunyai pengaruh yang signifikan secara simultan terhadap variabel kesiapsiagaan $(Y)$.

- $\quad$ Ha: $\beta 1=\beta 2 \neq 0$, artinya variabel pengetahuan (X1) dan sikap (X2) mempunyai pengaruh yang signifikan secara simultan terhadap variabel kesiapsiagaan $(\mathrm{Y})$. 
Kriteria yang digunakan yaitu:

- $\quad$ Bila (P Value $)<0,05$ maka H0 ditolak dan Ha diterima. Artinya variabel independen secara simultan (bersama-sama) mempengaruhi variabel dependen.

- $\quad$ Bila (P Value) >0,05 maka H0 diterima dan Ha ditolak. Artinya variabel independen secara simultan (bersama-sama) tidak mempengaruhi variabel dependen.

\section{Hasil dan Pembahasan}

Hasil

Berdasarkan data yang diperoleh, Kelurahan Sempaja terdiri dari $735 \mathrm{KK}$. Adapun jumlah penduduk dapat dilihat pada tabel 5 .

Tabel 5 Jumlah kepala keluarga di Kelurahan Sempaja Timur

\begin{tabular}{|c|c|c|c|c|}
\hline No. & Nama Perumahan & RT & Jumlah KK & $\begin{array}{c}\text { Jumlah } \\
\text { Penduduk }\end{array}$ \\
\hline 1. & Perum Puspita & 25 & 10 & 35 \\
\hline 2. & Perum Puspita & 26 & 15 & 54 \\
\hline 3. & Perum Bengkuring (Jl. Kestela) & 51 & 15 & 68 \\
\hline 4. & Perum Bengkuring (Jl. Kestela) & 35 & 55 & 135 \\
\hline 5. & Perum Bengkuring (Jl. Asparagus) & 36 & 179 & 451 \\
\hline 6. & Perum Bengkuring (Jl. Terong $1 \mathrm{~s} / \mathrm{d} 6$ ) & 37 & 124 & 435 \\
\hline 7. & Perum Bengkuring (Jl. Terong Pipit $1 \mathrm{~s} / \mathrm{d}$ 12) & 38 & 103 & 434 \\
\hline 8. & Perum Bengkuring (Jl. Pakis Aji $1 \mathrm{~s} / \mathrm{d}$ 6) & 46 & 30 & 110 \\
\hline 9. & Perum Bengkuring (Jl. Slada) & 40 & 25 & 51 \\
\hline 10. & Perum Bengkuring (Jl. Pakis Merah) & 44 & 35 & 103 \\
\hline 11. & Perum Bengkuring (Jl. Bayam) & 47 & 27 & 80 \\
\hline 12. & Perum Bengkuring (Jl. Bayam) & 49 & 32 & 78 \\
\hline 13. & Perum Bengkuring (Jl. Pakis Merah) & 45 & 25 & 79 \\
\hline 14. & Perum Griya Mukti & 50 & 35 & 116 \\
\hline 15. & Perum Bumi Sempaja & 01 & 25 & 98 \\
\hline & Jumlah & & 735 & 2.327 \\
\hline
\end{tabular}

Sumber: Kelurahan Sempaja Timur, 2019

Berdasarkan informasi dari Kelurahan Sempaja Timur melalui wawancara mendalam dengan Lurah Sempaja Timur, diperoleh informasi bahwa wilayah yang sering mengalami banjir terparah adalah perumahan Bengkuring tepatnya di Jl. Kestela, Jl. Asparagus dan JI Terong. Kedalaman banjir mencapai $75 \mathrm{~cm}$. Dapat dilihat pada gambar 2 banjir yang terjadi di perumahan Bengkuring pada tanggal 25 Juni 2019. Hal tersebut menjadi pertimbangan dalam melakukan pemilihan responden, karena warga tersebut lebih mempunyai pengalaman dalam menghadapi banjir. 


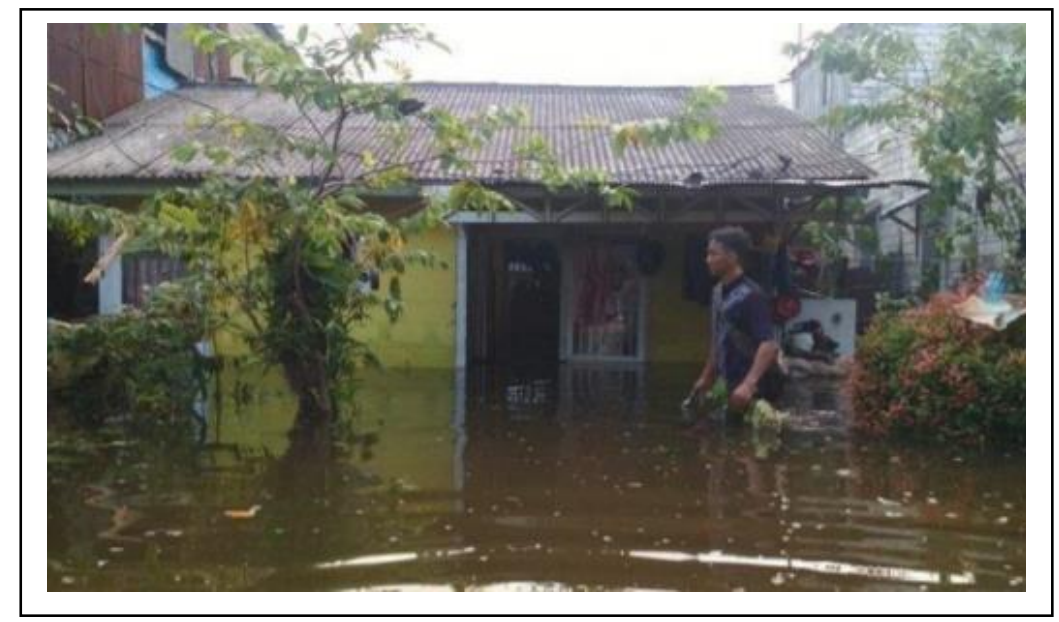

Gambar 2 Banjir di Perumahan Bengkuring Kelurahan Sempaja Timur

Penelitian ini dilakukan di Kelurahan Sempaja Timur Kecamatan Samarinda Utara Kota Samarinda. Pengumpulan data dilakukan bulan Juni sampai dengan Agustus 2020. Bahan yang digunakan adalah kuesioner dengan sampel adalah 199 kepala keluarga. Dalam banyak kesempatan, kepala keluarga bertindak sebagai perwakilan rumah tangga. Apabila kepala keluarga tidak berada ditempat, maka dapat diwakili oleh anggota keluarga lain yang dianggap mampu memberikan informasi.

Karakteristik responden berdasarkan variabel pengetahuan dari hasil tes dan skor angket yang telah diisi oleh responden. Responden memiliki kategori pengetahuan tinggi yaitu sebanyak 125 orang (62,8\%). Sedangkan responden yang memiliki kategori pengetahuan sangat tinggi yaitu sebanyak 74 orang $(37,2 \%)$. Karakterisitik variabel pengetahuan dapat dilihat pada gambar 3 .

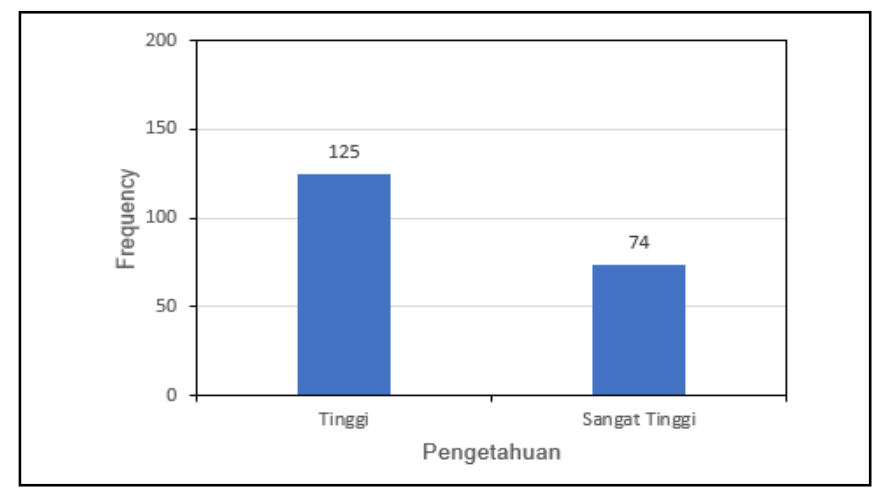

Gambar 3 Diagram batang variabel pengetahuan

Pada variabel sikap, mayoritas responden memiliki kategori sikap yang baik yaitu sebanyak 135 orang $(67,8 \%)$. Sedangkan responden yang memiliki kategori sikap yang sangat baik yaitu sebanyak 64 orang $(32,2 \%)$. Karakterisitik variabel sikap dapat dilihat pada gambar 4 . 


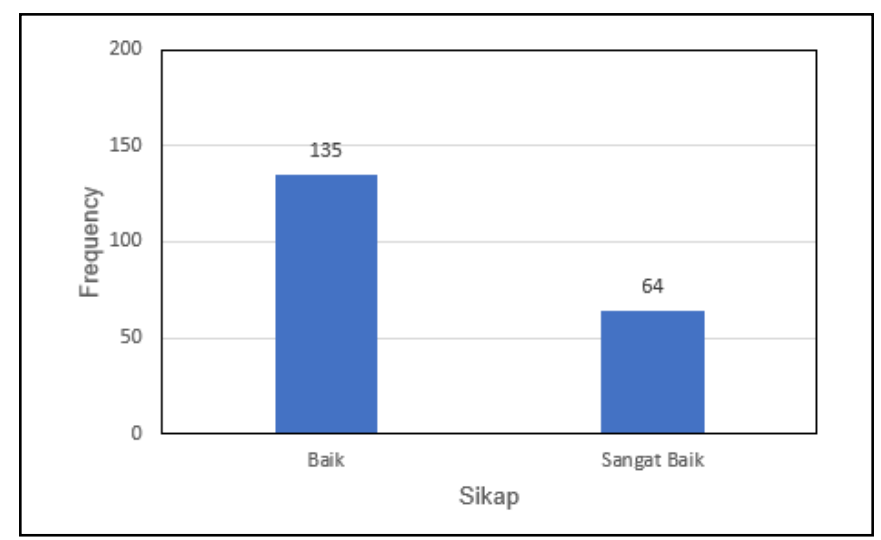

Gambar 4 Diagram batang variabel sikap

Tingkat kesiapsiagaan kepala keluarga dalam mengantisipasi bencana banjir di kelurahan Sempaja Timur secara umum dapat tercermin dalam bentuk indeks gabungan tiap parameter, yaitu indeks pengetahuan dan sikap, indeks rencana tanggap darurat, indeks mobilisasi sumber daya, dan indeks sistem peringatan bencana.

Parameter pengetahuan dan sikap meliputi pengertian bencana alam, pemahaman banjir, faktor penyebab bencana, dampak banjir, potensi kerugian yang disebabkan bencana banjir, pengertian kesiapsiagaan, tujuan rencana kesiapsiagaan, persiapan bahan makanan, upaya menghidari resiko bencana banjir, menerima, merespon dan bertanggungjawab atas keselamatan akibat bencana banjir. Parameter rencana tanggap darurat meliputi perlengkapan peralatan penyelamatan, dan evakuasi, memiliki cadangan pakaian, makanan dan minuman, kebijakan kepala keluarga untuk rencana menyelamatkan keluarga. Parameter mobilisasi sumber daya meliputi mempersiapkan tabungan atau asuransi jiwa dan harta benda, terlibat aktif dalam rapat untuk persiapan dan perencanaan pengurangan resiko bencana, ikut serta dalam kegiatan gotong royong membersihkan lingkungan, terlibat aktif dalam pembangunan sarana mitigasi dan terlibat aktif dalam kegiatan pelatihan-pelatihan atau simulasi tentang pengurangan resiko bencana. Parameter sistem peringatan bencana meliputi sumber informasi peringatan banjir yang diperoleh baik dari sosmed, pengumuman mesjid, informasi tetangga dan pemerintah. Tingkat kesiapsiagaan kepala keluarga dalam menghadapi banjir ditunjukkan pada tabel 6 .

Tabel 6 Tingkat kesiapsiagaan kepala keluarga dalam menghadapi banjir

\begin{tabular}{clcrrc}
\hline No. & Parameter Kesiapsiagaan & $\begin{array}{c}\text { Indeks } \\
\text { Kesiapsiagaan }\end{array}$ & Bobot & Indeks & $\begin{array}{c}\text { Tingkat } \\
\text { Kesiapsiagaan }\end{array}$ \\
\hline 1. & Pengetahuan dan Sikap & 86,66 & 0,45 & 38,21 & Siap \\
2. & Rencana Tanggap Darurat & 66,51 & 0,35 & 23,28 & Siap \\
3. & Mobilisasi Sumber Daya & 62,56 & 0,15 & 9,38 & Hampir Siap \\
4. & Sistem Peringatan Bencana & 47,74 & 0,05 & 2,39 & Kurang Siap \\
\hline
\end{tabular}

Sumber: Hasil Analisis Data 
Hasil perhitungan indeks yang telah dilakukan secara umum menunjukkan bahwa indeks gabungan kesiapsiagaan kepala keluarga di Kelurahan Sempaja Timur dalam kategori siap dengan nilai indeks 73.26. Dari empat parameter tersebut yang paling tinggi nilainya adalah parameter pengetahuan dan sikap dengan nilai mencapai 86.66 yaitu dalam kondisi siap. Parameter yang paling rendah nilainya adalah sistem peringatan bencana dengan nilai indeks 47.74 yaitu dalam kondisi kurang siap. Dan dua parameter lainnya yaitu rencana tanggap darurat dengan nilai 66.51 dan mobilisasi sumber daya dengan nilai 62.56 dengan kondisi siap dan hampir siap.

Berdasarkan tabel 6 tingkat kesiapsiagaan kepala keluarga dalam menghadapi banjir dapat dilihat pada gambar 5 .

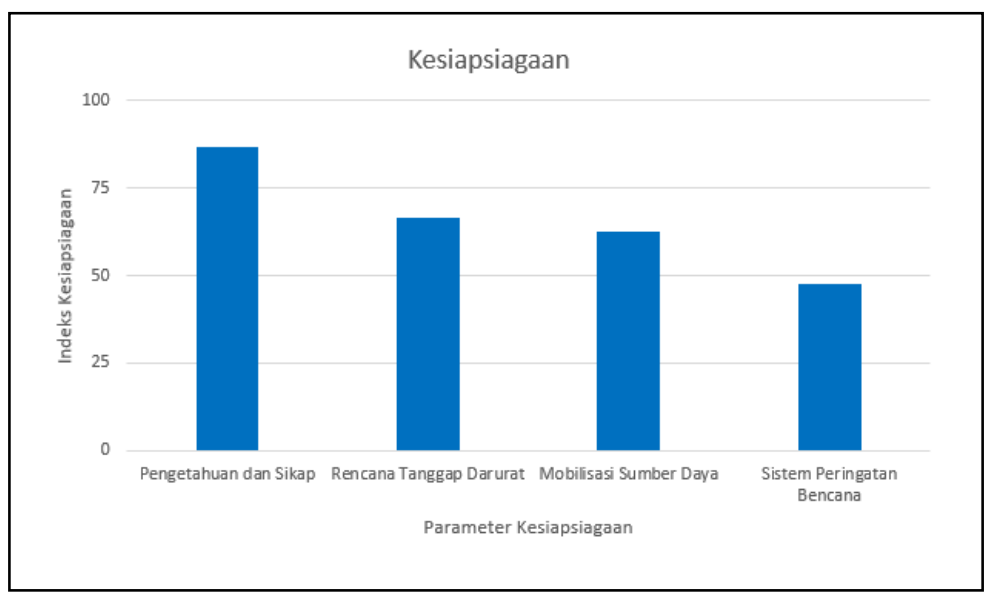

Gambar 5 Diagram batang tingkat kesiapsiagaan

Berdasarkan hasil regresi dengan menggunakan program SPSS (Jakaria, 2015), maka didapatkan koefisien regresi yang dapat dilihat pada tabel 7 .

Tabel 7 Hasil koefisien regresi linear berganda

\begin{tabular}{|c|c|c|c|c|c|c|}
\hline \multicolumn{7}{|c|}{ Coefficients $^{a}$} \\
\hline \multirow[b]{3}{*}{ Model } & & \multirow{2}{*}{\multicolumn{2}{|c|}{ Unstandardized Coefficients }} & \multirow{2}{*}{$\begin{array}{l}\text { Standardized } \\
\text { Coefficients }\end{array}$} & \multirow[b]{3}{*}{$\mathrm{T}$} & \multirow[b]{3}{*}{ Sig. } \\
\hline & & & & & & \\
\hline & & $\mathrm{B}$ & Std. Error & Beta & & \\
\hline 1 & (Constant) & 10.282 & 1.231 & & 8.349 & .000 \\
\hline & $\begin{array}{l}\text { Pengetahuan_X1 } \\
\text { Sikap X2 }\end{array}$ & $\begin{array}{l}.243 \\
.034\end{array}$ & $\begin{array}{l}.064 \\
.022\end{array}$ & $\begin{array}{l}.262 \\
.105\end{array}$ & $\begin{array}{l}3.811 \\
1.525\end{array}$ & $\begin{array}{l}.000 \\
.129\end{array}$ \\
\hline
\end{tabular}

a. Dependent Variable: Kesiapsiagaan_Y

Berdasarkan pada tabel 7 maka didapatkan persamaan regresi linier berganda sebagai berikut:

$$
Y=10,282+0,243 X 1+0,034 X 2+\text { error }
$$

Uji $\mathrm{F}$ pada penelitian ini merupakan uji yang dilakukan untuk mengetahui hubungan antara variabel independen dan variabel dependen, dapat dilihat pada tabel 8. 
Tabel 8 Hasil uji simultan (Uji F)

\begin{tabular}{|c|c|c|c|c|c|c|}
\hline \multicolumn{7}{|c|}{ ANOVA $^{\mathrm{a}}$} \\
\hline Model & & $\begin{array}{l}\text { Sum of } \\
\text { Squares }\end{array}$ & Df & Mean Square & $\mathrm{F}$ & Sig. \\
\hline 1 & $\begin{array}{l}\text { Regression } \\
\text { Residual } \\
\text { Total }\end{array}$ & $\begin{array}{r}13.895 \\
169.557 \\
183.452\end{array}$ & $\begin{array}{r}2 \\
196 \\
198\end{array}$ & $\begin{array}{r}6.947 \\
.865\end{array}$ & 8.031 & $.000^{\mathrm{b}}$ \\
\hline
\end{tabular}

a. Dependent Variable: Kesiapsiagaan_Y

b. Predictors: (Constant), Sikap_X2, Pengetahuan_X1

\section{Pembahasan}

Bencana merupakan peristiwa yang mengancam dan mengganggu kehidupan dan penghidupan masyarakat yang disebabkan oleh faktor alam dan/atau faktor non alam maupun faktor manusia sehingga mengakibatkan timbulnya korban jiwa manusia, kerusakan lingkungan, kerugian harta benda, dan dampak psikologis (UU nomor 24, 2007). Menurut BNPB (2012) banjir sebagai salah satu bencana alam adalah peristiwa meluapnya air yang menggenangi permukaan tanah, dengan ketinggian melebihi batas normal. Banjir umumnya terjadi pada saat aliran air melebihi volume air yang yang dapat ditampung dalam sungai, danau, rawa, drainase, tanggul maupun saluran air lainnya pada selang waktu tertentu. Dampak banjir yang bersifat nyata dan terukur secara ekonomi antaralain kerusakan bangunan, infrastruktur, hasil pertanian/peternakan, keterlambatan pasaokan barang-barang kebutuhan pokok dan sebagainya. Sedangkan dampak lainnya adalah timbulnya korban luka-luka maupun korban jiwa serta rusaknya lingkungan. Tingginya curah hujan biasanya menjadi salahsatu faktor penyebab terjadinya banjir di daerah perkotaan. Sama halnya banjir yang terjadi di perumahan Bengkuring kelurahan Sempaja Timur pada 25 Juni 2019 dan terjadi lagi pada 22 Mei 2020. Curah hujan pada saat itu mencapai 363.1 milimeter yang termasuk dalam kategori sangat tinggi. Oleh karena itu, sangat penting bagi masyarakat untuk mewaspadai banjir dengan meningkatkan kesiapsiagaan individu/rumahtangga dalam mengantisipasi bencana khusus nyadi daerah rawan banjir.

Pengetahuan yang dimiliki mempengaruhi sikap dan kepedulian masyarakat untuk siap dan siaga dalam mengantisipasi bencana, terutama bagi mereka yang bertempat tinggal di daerah yang rentan terhadap bencana alam (Indawati, 2015). Kepala keluarga yang memiliki kategori pengetahuan tinggi yaitu sebanyak 125 orang $(62,8 \%)$ dan kategori pengetahuan sangat tinggi yaitu sebanyak 74 orang $(37,2 \%)$. Sedangkan kepala keluarga yang memiliki kategori sikap yang baik yaitu sebanyak 135 orang $(67,8 \%)$ dan kategori sikap yang sangat baik yaitu sebanyak 64 orang $(32,2 \%)$. Notoatmojo (2007) mengemukakan bahwasanya peningkatan pengetahuan yang dimiliki oleh seorang individu akan memilki korelasi dengan peningkatan perilaku dari individu 
tersebut. Pengetahuan dan sikap serta kesiapsiagaan yang dimiliki oleh masyarakat khususnya di Kelurahan Sempaja Timur diperoleh dari pengalaman mengalami bencana banjir hampir setiap tahun. Pengalaman tersebut memberikan pengetahuan tentang bencana banjir yang melanda dan mempengaruhi sikap dan kepedualian masyarakat untuk siap siaga mengantisipasi banjir. Berdasarkan penelitian yang dilakukan menunjukan bahwa kesiapsiagaan kepala keluarga dalam menghadapi banjir dengan nilai 73.26. Hal ini menunjukan bahwa secara umum mereka memiliki kemampuan mengenali dan merespon banjir yang berpotensi terjadi di lingkungan tempat tinggal mereka. Kesiapan suatu rumah tangga dalam menghadapi bencana banjir berdampak positif sehingga tidak menyebabkan kerugian besar bagi rumah tangga seperti kerusakan perumahan, perabot rumah tangga, dan lingkungan sekitar.

Dibandingkan dengan parameter kesiapsiagaan bencana yang lain, pengetahuan dan sikap merupakan parameter dengan nilai indeks tertinggi yaitu 86.66. Hal ini menunjukkan bahwa tingkat kesiapsiagaan kepala keluarga dalam menghadapi banjir sebagian besar ditentukan oleh pengetahuan dan sikap mereka terkait dengan bencana alam tersebut. Dibuktikan pada persamaan regresi linier berganda: $Y=10.282+0.243$ X1 + 0.034 X2, diperoleh nilai konstanta sebesar 10.282. Hal tersebut berarti, apabila kondisi variabel pengetahuan (X1) dan sikap (X2) dianggap konstan, maka kesiapsiagaan $(Y)$ yang dihasilkan adalah sebesar 10.282. Nilai 0.243 pada variabel pengetahuan (X1) adalah bernilai positif sehingga dapat dikatakan bahwa variabel pengetahuan berpengaruh positif terhadap kesiapsiagaan (Y). Nilai 0.034 pada variabel sikap (X2) adalah bernilai positif sehingga dapat dikatakan bahwa variabel sikap berpengaruh positif terhadap kesiapsiagaan $(\mathrm{Y})$. Begitupula pada hasil uji $\mathrm{F}$ pada penelitian ini didapatkan nilai $F$ hitung sebesar 8.031 dengan angka signifikansi ( $P$ value) sebesar 0.000 . Dengan tingkat signifikansi 95\% $(\alpha=0.05)$. Angka signifikansi ( $P$ value) sebesar $0.000<0.05$. Atas dasar perbandingan tersebut, maka $\mathrm{H} 0$ diterima atau berarti variabel pengetahuan (X1) dan sikap (X2) mempunyai pengaruh yang signifikan secara simultan terhadap variabel kesiapsiagaan $(Y)$.

Secara umum warga perumahan Bengkuring Kelurahan Sempaja Timur mengetahui bahwa bencana yang sering terjadi di tempat tinggal mereka adalah banjir yang disebabkan karena karena luapan air sungai dan tingginya curah hujan. Selain itu, mereka juga memahami bahwa tindakan yang harus mereka lakukan apabila terjadi banjir adalah berlindung ke tempat yang lebih aman dan berlari ke tempat pengungsian. Hasil penelitian LIPI-UNESCO pada tahun 2006 menunjukan bahwa pengetahuan masyarakat tentang bencana mempengaruhi sikap dan kepedulian individu/ rumah tangga untuk siap dan siaga dalam mengantisipasi terjadinya bencana, sehingga 
dampak ikutan bencana dapat meminamilisir. Kondisi seperti ini yang kiranya berkontribusi dalam pengurangan dampak bencana banjir di kelurahan Sempaja Timur.

Kesiapsiagaan kepala keluarga di kelurahan Sempaja Timur juga dipengaruhi oleh rencana tanggap darurat dengan nilai indeks 66.5. Rencana tanggap darurat menjadi bagian yang penting dalam proses kesiapsiagaan, terutama yang terkait dengan evakuasi, penyelamatan, agar korban bencana dapat diminimalkan (Firmansyah, 2014). Kepala keluarga mengetahui apa yang harus dilakukan untuk menyelamatkan diri dari banjir seperti menambah pengetahuan tentang banjir, adanya kesepakatan tempat pengungsian/ evakuasi, mengetahui tempat menyelamatkan diri pada saat banjir terjadi, dan ada kotak obat. Hal ini mencerminkan bahwa partisipasi kepala keluarga maupun pemerintah dalam hal ini kelurahan Sempaja Timur terbilang aktif dalam menyusun perencanaan tanggap darurat yang meliputi aspek evakuasi, pertolongan dan penyelamatan. Terdapat tenaga sukarela lokal yang tergabung dalam kelompok KATANA (Kelurahan Tanggap Bencana). Tinggi rendahnya nilai indeks rencana tanggap darurat juga dipengaruhi oleh pengalaman masyarakat. Masyarakat di kelurahan Sempaja Timur sudah sering mengalami banjir sebab wilayah yang mereka huni memiliki riwayat sebagai daerah rawan banjir. Fakta dilapangan juga mendukung hal tersebut sebab apabila musim penghujan tiba dengan intensitas dan curah hujan yang tinggi, maka daerah ini akan mengalami banjir. Apabila banjir terjadi, pengalaman mereka berkontribusi dalam pelaksanaan rencana tanggap darurat keluarga mereka. Hal ini sejalan dengan penelitian Sagala (2014) di kabupaten Bandung yang menunjukkan bahwa riwayat bencana banjir yang telah lama terjadi, menjadikan masyarakat terbiasa melakukan berbagai tindakan untuk mengurangi risiko yang mereka alami seperti menyiapkan langkah-langkah dalam menghadapi bencana banjir, menyiapkan rencana aksi dalam menghadapi bencana banjir, melakukan pembagian peran anggota keluarga dan masyarakat, menyiapkan tempat evakuasi, dan menyiapkan berbagai perlengkapan gawat darurat.

Parameter kesiapsiagaan berikutnya adalah mobilisasi sumberdaya dan sistem peringatan bencana. Kedua parameter ini berada dalam kondisi hampir siap dan kurang siap, dengan nilai indeks masing-masing adalah 62.56 dan 47.74. Nilai indeks mobilisasi sumberdaya yang berada pada kategori hampir siap menjadi indikasi kurang atau rendahnya kapasitas kepala keluarga dalam menggerakkan sumberdaya mereka pada saat dan setelah banjir terjadi. Hal ini disebabkan kurangnya keterampilan mereka dalam hal pertolongan pertama, kesiapsiagaan, evakuasi korban dan pengolahan air bersih. Tindakan kesiapsiagaan yang dilakukan oleh warga bukan berasal dari pelatihan atau pemberitahuan dari pemerintah melainkan pengalaman mereka yang telah lama 
mengalami bencana banjir (Novian, 2018). Kalaupun ada pelatihan terkait, maka hanya diikuti oleh sebagian kecil warga saja. Keberadaan tabungan dan asuransi sebagai bagian dari sumberdaya keluarga juga belum, minat, akses ataupun informasi terkait keduanya yang masih terbatas untuk kalangan tertentu. Namun demikian, kebiasaan tolong-menolong antar sesama keluarga sangat baik menjadi penutup celah kurangnya sumberdaya keluarga yang lain. Sebagian besar individu/ rumah tangga mengaku mempunyai kerabat atau teman yang siap membantu apabila terjadi banjir. Hal ini mengurangi beban dan resiko terkait banjir yang yang kerap terjadi didaerah ini, namun tetap perlu didukung dengan upaya perbaikan terhadap faktor lain seperti sistem peringatan bencana.

Indikator kesiapsiagaan adalah bagaimana sistem peringatan dini yang ada di masyarakat, terutama di daerah yang memiliki kerentanan bencana banjir. Sistem peringatan meliputi tanda peringatan dan distribusi informasi jika terjadi bencana (Dodon, 2013). Sistem peringatan bencana yang kurang siap menggambarkan rendahnya pengetahuan dan ketersediaan teknologi terkini yang terkait dengan sistem ini. Gambaran mengenai sistem peringatan bencana di kelurahan Sempaja Timur menunjukkan bahwa penting untuk segera melakukan sosialisasi, fasilitasi, dan pelatihan oleh pemerintah mengenai sistem peringatan bencana, terutama pada masa sebelum banjir terjadi. Menurut Susanto (2006) dalam kondisi bencana, tidak mudah untuk menerapkan berbagai kebijakan yang terkait dengan kesiapsiagaan. Oleh sebab itu, pada kondisi aman perlu dilakukan berbagai upaya pencegahan, termasuk membangun dan mengembangkan sistem peringatan bencana non tradisional meskipun skala kecil di lingkungan tempat tinggal mereka.

\section{Kesimpulan}

Berdasarkan hasil analisis dan pembahasan, dapat disimpulkan bahwa terdapat pengaruh yang signifikan antara pengetahuan dan sikap terhadap tingkat kesiapsiagaan kepala keluarga dalam menghadapi banjir di Kelurahan Sempaja Timur. Hal ini dibuktikan pada persamaan regresi linier berganda: $Y=10.282+0.243 \mathrm{X} 1+0.034 \mathrm{X} 2$. Begitupula pada hasil uji $F$ didapatkan nilai $F$ hitung sebesar 8.031 dengan angka signifikansi ( $P$ value) sebesar 0.000. $<0.05$ (tingkat signifikansi 95\%, $\alpha=0.05$ ). Indeks gabungan dari empat parameter yaitu pengetahuan dan sikap, rencana tanggap darurat, mobilisasi sumber daya dan sistem peringatan banjir mencapai 73.26. Angka ini dalam klasifikasi indeks kesiapsiagaan termasuk kategori siap. 


\section{Daftar Pustaka}

Arikunto, S. (2010). Prosedur Penelitian Suatu Pendekatan Praktek. Jakarta. Rineka Cipta.

Aryono, D.P. (2011). The Silent Disaster Bencana dan Korban Massal. Jakarta: CV. Sagung Seto.

Bakornas PB (2007). Pengenalan Karakteristik Bencana dan Upaya Mitigasinya di Indonesia. Jakarta: Badan Nasional Penanggulangan Bencana.

Badan Nasional Penanggulangan Bencana (2012). Pedoman Umum Pengkajian Risiko Bencana. Jakarta: Badan Nasional Penanggulangan Bencana.

Badan Nasional Penanggulangan Bencana (2019). Pedoman Umum Pengkajian Risiko Bencana. Jakarta: Badan Nasional Penanggulangan Bencana.

Badan Penanggulangan Bencana Daerah Kota Samarinda (2012). Peta Kawasan Rawan Bencana Banjir Dan Tanah Longsor Kota Samarinda. Samarinda: Badan Penanggulangan Bencana Daerah Kota Samarinda.

Badan Penanggulangan Bencana Daerah Kota Samarinda (2019). Peta Kawasan Rawan Bencana Banjir Dan Tanah Longsor Kota Samarinda. Samarinda: Badan Penanggulangan Bencana Daerah Kota Samarinda.

Dodon (2013). Indikator dan Perilaku Kesiapsiagaan Masyarakat di Permukiman Padat

Penduduk Dalam Antisipasi Berbagai Fase Bencana Banjir. Jurnal Perencanaan Wilayah dan Kota, 21(2).

Firmansyah, I., Rasni, H., \& Rondhianto. (2014). Hubungan Pengetahuan dengan Perilaku Kesiapsiagaan dalam Menghadapi Bencana Banjir dan Longsor pada Remaja Usia 15-18 tahun di SMA Al-Hasan Kemiri Kecamatan Panti Kabupaten Jember. Artikel ilmiah Hasil Penelitian Mahasiswa, 1-8.

Jakaria, Y (2015). Mengolah Data Penelitian Kuantitatif Dengan SPSS. Bandung: CV. Alfabeta.

LIPI-UNESCO (2006). Kajian Kesiapsiagaan Masyarakat dalam mengantisipasi Bencana Gempa Bumi dan Tsunami. Jakarta: Deputi Ilmu Pengetahuan Kebumian Lembaga Imu Pengetahuan Indonesia.

Notoatmodjo, S (2005). Promosi Kesehataan: Teori dan Aplikasinya. Jakarta: Rineka Cipta.

Novian, A. A. (2018), Pengetahuan dan Kesiapsiagaan Masyarakat Terhadap Bencana Banjir di Kota Bekasi (Studi Kasus: Perumahan Pondok Gede Permai). Jurnal Alami, 2(1). 
Sagala, S., Dodon \& Wimbardana (2014). Adaptasi Non Struktural Penduduk Penghuni Permukiman Padat Terhadap Bencana Banjir Kabupaten Bandung. Jurnal Nasional Teknik Sipil, 5(1).

Sugiyono (2013). Metode Penelitian Kuantitatif, Kualitatif dan R\&D. Bandung: CV. Alfabeta.

Susanto, A.B. (2006). Disaster Management di Negara Rawan Bencana: Sebuah Pendekatan Strategic Management. Jakarta: The Jakarta Consulting Group. Undang-undang No. 24 (2007) Tentang Penanggulangan Bencana, Jakarta. 